\title{
제833회 $\mathrm{OECD}$ 개발원조위원회 정기회의 결과
}

\section{I. 핵심요지}

$\mathrm{OECD}$ 개발 - 환경장관 합동회의를 2006년 5월 개최하는 방안에 대하여 독일을 제외한 대다수 회 원국이 적극 지지입장을 표명하였으며 세부사항 은 계속 논의키로 함.

ㅁ원조효과 증진에 관한 파리 고위급포럼의 후속조 치의 일환으로 원조효과 작업반 회의를 2005. 5. 30 31간 개최하고 Non-DAC 공여국을 위한 브 리핑을 2005. 9. 27 29간 개최키로 함

\section{II . DAC Outreach 전략 추진 합의}

Outreach 전략 일반사항

-Outreach의 대상을 5 개 그룹(non-DAC OECD 회원국, non-OECD 공여국, 수원국, 국 제기구, NGO)으로 분류
-Outreach의 수단으로서 기존에 해오던 계속적 인 회의참여 외에

· Non-DAC 공여국의 통계능력 지원,

- ODA 담당자를 위한 브리핑(structured briefing) 실시

- 회원국의 국별심사에 Non-DAC 공여국의 참 여(silent observer 자격)

- Non-OECD EU 회원국 및 주요 신흥공여국 (BRICS)에 $\mathrm{OECD}$ 문서검색시스템(OLIS) 접근 허용

- Non-DAC 공여국과의 정책대화 회의 개최 등 을 추진

- Non-OECD 공여국은 다시 4개 그룹(1)쿠웨이 트, 사우디, $\mathrm{UAE}$ 등 전통적 공여국 (2)브라질, 인도, 러시아, 중국, 남아공 등 주요 신흥공여국 (3)Non-OECD EU 회원국 (4)여타 Non-OECD 공여국)으로 분류하여 그룹별로 적합한 사업 시 행 및 모니터링 실시 
№n-DAC 공여국을 위한 브리핑(Structured Briefing) 계획

- 일시:2005. 9. 27 29간 OECD 본부에서 2 3 일간 일정

- 대상:한국 포함 23 개 신흥공여국의 개발원조 담당자(아랍권 공여국들은 제외)

-목적:DAC의 정책지침 설명 및 신흥공여국의 개발원조에 대한 의견교환

-주요 의제:성장과 빈곤완화, 원조관리, 원조효 과, 원조의 치안측면, 정책일관성, 통계, 개발센 터 등

$\square$ Global Forum on Development

-DAC의 outreach 전략의 일환으로 기존의 Partnership Forum을 Global Forum으로 대 체하고

- 개발클러스터 및 전체 $\mathrm{OECD}$ 작업의 일관성 (coherence) 증진에 초점을 맞추며

-주요 의제로는 아프리카 원조 증진, 파리선언 후 속조치, 원조의 언타이드화, 빈곤퇴치를 위한 인 프라시설의 역할, Aid architecture 등을 추진 키로 잠정 합의

\section{III. 원조효과 증진에 관한 파리 고위급} 포럼 후속조치 추진 합의

ㅁAC의 원조효과작업반 회의를 2005. 5. 30 31 간 개최

ㅁ사무국은 파리선언에서 확정되지 않은 일부 지표
의 목표(target) 도출을 위한 기초정보(baseline information)를 수집 중인 바, 이에 관한 feedback을 5월 중순까지 제공하고 2005년 9월 까지 target에 합의할 수 있는 방안 제시 요망

믁간 원조효과작업반 회의에 참여하였던 모든 수 원국(총 22 국)을 5 월 회의에도 초청

ㅁㅊㅜㅜ 원조효과작업반회의에도 수원국 약 20 개국 (여비 지원) 및 지역개발은행, 국제기구를 참여시 키되 $\mathrm{NGO}$ 는 초청하지 않음.

\section{$\mathrm{IV}$. DAC의 홍보전략 추진}

ㅁ $\mathrm{DAC}$ 의 새로운 홍보전략의 대상은 본국 정부의 $\mathrm{ODA}$ 담당관 및 현장 관리자들이라는데 합의

ㅁ $\mathrm{DAC}$ 에서 주요 정책 및 지침을 생산하고 있지만 본국의 정책담당관들에 의해 읽혀지지 않고 있다 는 문제점이 주로 지적되었고 새로운 홍보전략의 초점을 $\mathrm{ODA}$ 담당관 및 현장관리자들이 $\mathrm{DAC}$ 문 서를 읽을 수 있도록 효과적으로 전달하고 모범관 행(good practice)이 일반관행 (general practice) 이 되도록 하는데 맞추기로 함.

\section{$\mathrm{V}$. 통계개발 지원}

마라케쉬 행동계획의 권고에 따라 모든 저소득국 은 국가통계개발전략(NSDS)을 2006년까지 준비 하게 되어 있고 이에 따라 PARIS21(OECD 사무 
국 추진 통계협력프로그램)은 81개 저소득국의 $\mathrm{NSDS}$ 수립을 지원하고 있음.

ㅁㅡㅡㅁ번 회의에서 PARIS21의 연간활동보고서(통계 개발을 위한 국별전략 문서)를 승인함.

\section{VI. 개발 - 환경장관 합동회의 개최}

\footnotetext{
ㅁ 개발 - 환경장관 합동회의를 2006 년 5 월 개최하는 방안에 대하여 논의한 바, 다소 유보적 입장을 보 인 독일을 제외한 대다수 국가가 적극적 지지입장 을 표명하였음.

맙봉회의 준비 관련 세부사항은 $\mathrm{DAC}$ 및 $\mathrm{EPOC}$ 산하 해당 작업반에서 추가 논의하되 최종결정은 작업반이 아닌 위원회에서 결정키로 함.

[자료:주오이시디 대표부] 